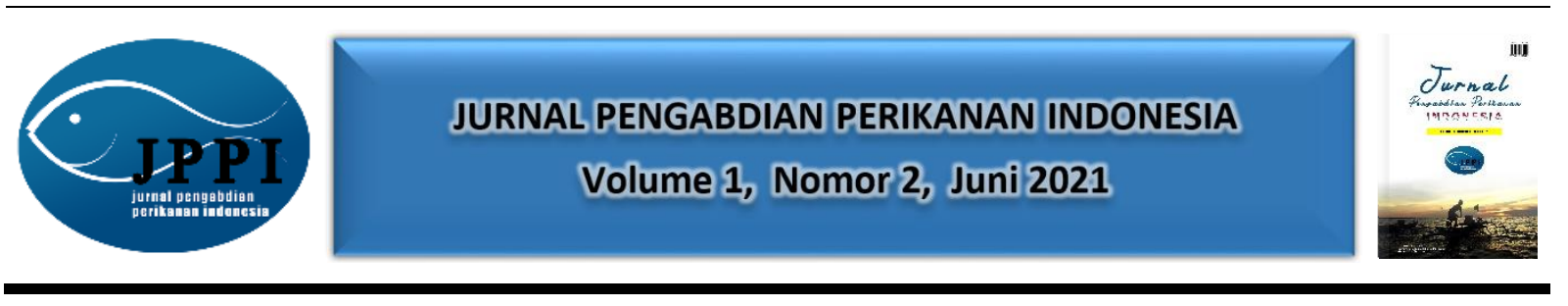

\title{
DEMPLOT BUDIDAYA LOBSTER (PANULIRUS HOMARUS) SITEM KERAMBA JARING APUNG DENGAN PAKAN SUPLEMENTASI SPIRULINA PLATENSIS DI KABUPATEN LOMBOK UTARA
}

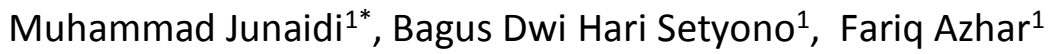 \\ ${ }^{1}$ Program Studi Budidaya Perairan Universitas Mataram \\ Jl. Majapahit No. 62 Mataram, Nusa Tenggara Barat \\ *Alamat Korespondensi: E-mail: m.junaidi@unram.ac.id
}

(Tanggal Submission: 1 Juni 2021, Tanggal Accepted : 29 Juni 2021)

\section{Keyword: Abstrak :}

demplot, Demplot budidaya dengan pakan suplementasi sprirulina plaensis dilakukan dengan lobster, spirulina, suplemen tujuan untuk meningkatkan performa pertumbuhan dan kelangsungan hidup lobster yang dipeliharan keramba jaring apung. Metode pelaksanaan pengabdian ni adalah metode transfer teknologi, dengan langkah-langkah yang telah disepakati bersama antara lain sosialisasi kegiatan, demonstrasi plot (demplot) budidaya lobster dalam keramba jaring apung dan pendampingan. Hasil kegiatan ini memberikan nilai posisif bagi masyarakat sasaran dan dapat meningkatkan performa pertumbuhan dan kelangsungan hidup lobster dengan pertumbuhan berat berkisar antara 387,06 424,21 \%, laju pertumbuhan spesifik erkisar antara 3,12 - 3,36 \%/hari dan kelangsungan hidup berkisar antara 93,33-100,00\%. Diharapkan dengan selesainya kegiatan pelaksanaan pengabdian ini keberlanjutan program terus dilakukan bahkan diperluas, sehingga tujuan dan manfaat program dapat tercapai dan berkontribusi pada peningkatan kualitas hidup dan pendapatan masyarakat.

Panduan Sitasi (APPA $7^{\text {th }}$ edition) :

Junaidi, M., Setyono, B.D.H., \& Azhar, F. (2021). Demplot Budidaya Lobster (Panulirus Homarus) Sitem Keramba Jaring Apung Dengan Pakan Suplementasi Spirulina Platensis Di Kabupaten Lombok Utara. Jurnal Pengabdian Perikanan Indonesia, 1 (2), 141-150. http://doi.org/ 10.29303/jppi.v1i2.134 


\section{PENDAHULUAN}

Budidaya lobster merupakan peluang usaha yang sangat menarik bagi sebagian besar masyarakat pesisir di Indonesia, karena penangkapan benih dari alam dan usaha budidayanya dapat dilakukan dengan teknologi yang sederhana dan modal yang relatif tidak terlalu besar (Erlania et al., 2016). Usaha budidaya lobster di Indonesia berkembang sejak tahun 2000 (Mustafa, 2013), awalnya merupakan usaha sampingan masyarakat di Teluk Ekas Provinsi Nusa Tenggara Barat (NTB), karena pada waktu itu banyak ditemukan benih alam yang menempel pada pelampung budidaya rumput laut dan kerapu. Benih-benih tersebut diambil dan dipelihara dalam keramba jaring apung (KJA), sehingga usaha budidaya lobster menjadi penggerak utama perekonomian masyarakat pesisir yang menggantikan usaha penangkapan lobster di alam (Junaidi \& Heriati, 2017; Junaidi \& Hamzah, 2014). Sampai akhir tahun 2003, usaha budidaya lobster dalam KJA yang dilakukan masyarakat dapat dikatakan cukup berhasil dengan tingkat kelangsungan hidup mencapai 93-100\% (Aslianti et al. 2004). Namun setelah itu, usaha budidaya lobster banyak mengalami kegagalan sehingga masyarakat lebih tertarik melakukan usaha penangkapan benih lobster. Penangkapan benih lobster mulai marak dilakukan di Pulau Lombok sejak tahun 2011 karena permintaan eksport cukup tinggi dan mencapai puncaknya pada tahun 2013 dengan hasil tangkapan mencapai 2,6 juta ekor dengan nilai Rp 36 milyar (Bahrawi et al., 2015).

Munculnya regulasi tentang larangan penangkapan benih lobster melalui Permen KP No. 1 tahun 2015 dan diperkuat dengan Permen KP No. 56 tahun 2016, sehingga sejak tahun 2015 kegiatan penangkapan benih lobster sudah tidak dilakukan. Pemerintah melalui Kementerian Kelautan dan Perikanan (KKP) telah mengeluarkan regulasi baru terkait komoditas lobster. Regulasi tersebut adalah Permen KP No. 12 tahun 2020, dalam regulasi tersebut memberi izin ekspor benih lobster. Sementara ekspor benih lobster yang sebelumnya dilarang sudah diperboleh dengan syarat tertentu atau sistem kuota, sehingga kegiatan penangkapan benih lobster kembali marak. Ternyata kebijakan terakhir ini menguntungkan dalam jangka pendek dan rawan penyimpangan, karena itu KKP kembali menerbitkan Permen No. 17 tahun 2021 yang melarang ekspor benih lobster sebagai upaya untuk mendorong pertumbuhan budidaya lobster di Indonesia dan mendorong pertumbuhan ekonomi (Kompas.com). Bahkan Provinsi Nusa Tenggara Barat akan dijadikan sebagai pusat budidaya lobster dan shrimp estate (suarantb.com).

Kabupaten Lombok Utara (KLU) merupakan salah satu kabupaten pesisir di Provinsi NTB, selain memiliki potensi potensi wisata bahari yaitu di Kawasan Gili Matra, perairan laut KLU memiliki memiliki potensi untuk pengembangan budidaya laut. Sampai saat ini kegiatan budidaya laut yang dikembangkan adalah komoditas kerapu dan lobster, serta kerang mutiara (Junaidi et al., 2018a; Junaidi et al., 2018b). Usaha budidaya kerang mutiara telah berkembang dalam skala industri sejak tahun 1980-an, yang dikelola perusahaan bahkan salah satu perusahaan mutiara terbesar di dunia berlokasi di perairan Kabupaten Lombok Utara. Sementara usaha budidaya ikan kerapu dan bawal dalam KJA masih dalam skala kecil, dimana Kelompok Pembudidaya Ikan (Pokdakan) Mekar Bahari di Desa Jenggala Kecamatan Tanjung merupakan salah satu kelompok masyarakat yang mengusahakan budidaya dalam KJA (Junaidi et al., 2020). Dengan demikian, untuk mendukung kebijakan KKP menjadikan Provinsi NTB sebagai pusat budidaya lobster di Indonesia, maka perlu upaya menyiapan sumberdaya manusia (SDM) yang mampu menyelesaikan permasalahan budidaya lobster terutama terkait belum tersedianya pakan buatan yang sesuai untuk pertumbuhan lobster (Erlania et al., 2016). Dalam budidaya lobster, para pembudidaya menggunakan ikan rucah sebagai pakan 
utama, dimana penggunaan ikan rucah sebagai pakan memiliki kelemahan diantaranya dibutuhkan ikan rucah dalam jumlah yang banyak, kandungan air yang tinggi dan rentan terhadap timbulnya penyakit pada lobster, dan sisa pakan yang tidak dikonsumsi oleh lobster dapat menurunkan kualitas perairan (Ridwanudin et al., 2018). Ketersedian dan keterjangkauan ikan rucah lebih mudah sehingga tetap digunakan oleh pembudidaya, sehingga perlu penambahan suplemen pada pakan ikan rucah. Salah satu bahan yang dapat dimanfaatkan sebagai sumber protein sel tunggal dan dapat meningkatan pertumbuhan lobster adalah spirulina (Hadijah et al., 2020; Utomo et al., 2012).

Berdasarkan uraian di atas, maka dilaksanakan kegiatan Pengabdian kepada Masyarakat (PkM) dalam rangka peningkatan pengetahuan dan keterampilan berupa demplot budidaya dengan pakan suplementasi sprirulina plaensis dengan tujuan untuk meningkatkan performa pertumbuhan dan kelangsungan hidup lobster yang dipeliharan keramba jaring apung.

\section{METODE PELAKSANAAN}

\section{Khalayak Sasaran}

Khalayak sasaran Pengabdian kepada Masyarakat (PkM) ini adalah Kelompok Pembudidaya Ikan (Pokdakan) Mekar Bahari. Pokdakan Mekar Bahari terletak di Dusun Penyambuan Desa Jenggala Kecamatan Tanjung Kabupaten Lombok Utara Provinsi Nusa Tenggara Barat (Gambar 1). Kegiatan PkM dilaksanakan pada bulan Agustus sampai Oktober 2019.

\section{Bahan dan Alat}

Rancangan kegiatan dalam memberikan solusi untuk meningkatkan pertumbuhan lobster dalam keramba jaring apung dengan menggunakan metode demonstrasi plot (demplot) budidaya lobster dengan pakan suplementasi sprirulina plaensis. Demplot budidaya lobster dilakukan pada 15 buah jaring apung berukuran $1 \times 1 \times 1 \mathrm{~m}^{3}$ yang dipasang pada kerangka KJA (Gambar 2). Bibit lobster (Panulirus homarus) yang digunakan berukuran 3-6 g sebanyak 300 ekor yang diperoleh dari nelayan benih lobster di Teluk Awang Lombok Tengah. Pakan lobster berupa ikan rucah yang telah dicampur dengan tepung spirulina sebanyak $0-0,4 \%$ (Gambar 3).

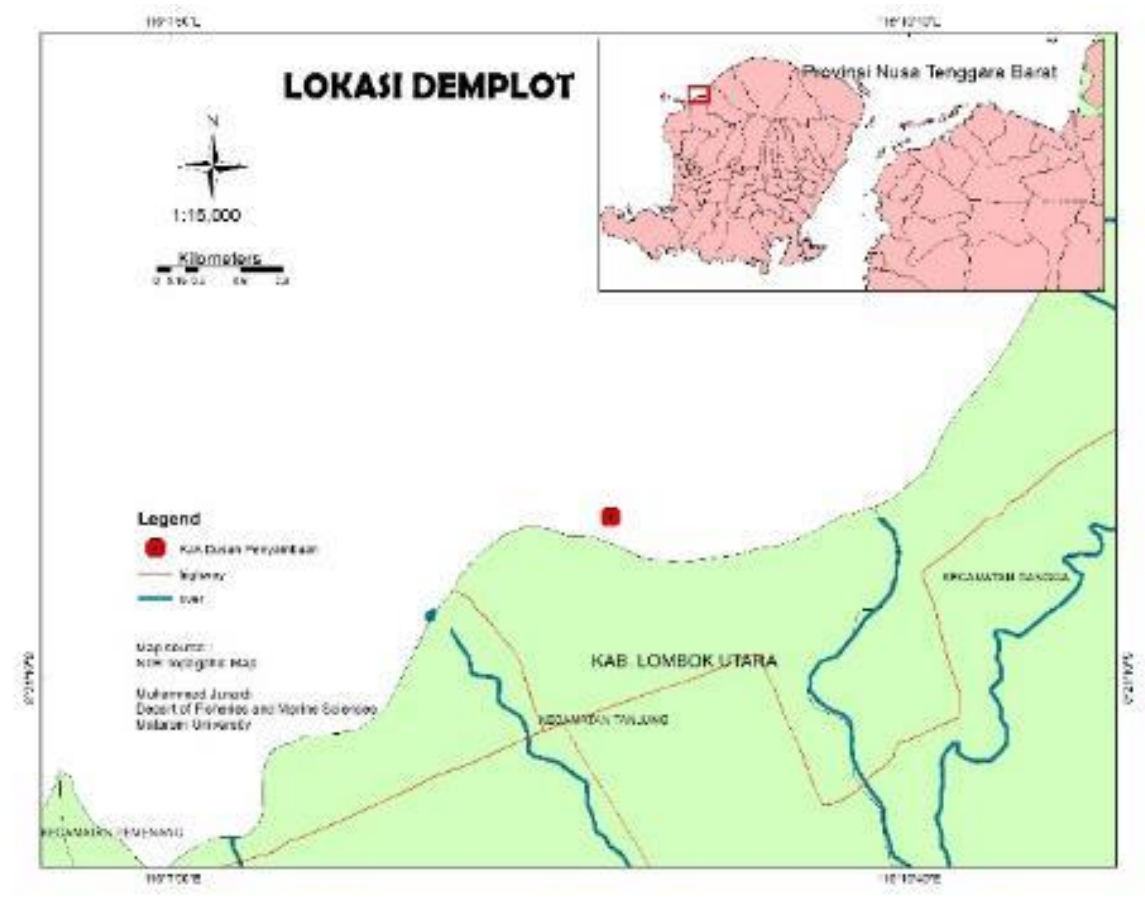

Gambar 1. Lokasi kegiatan demplot budidaya lobster 


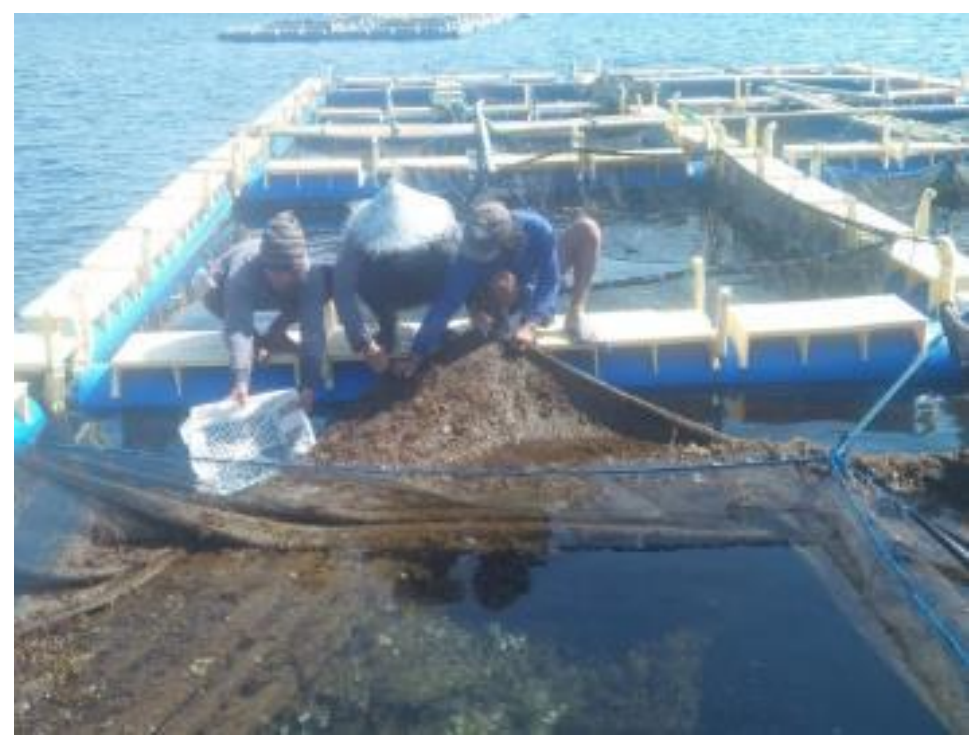

Gambar 2. KJA budidaya lobster

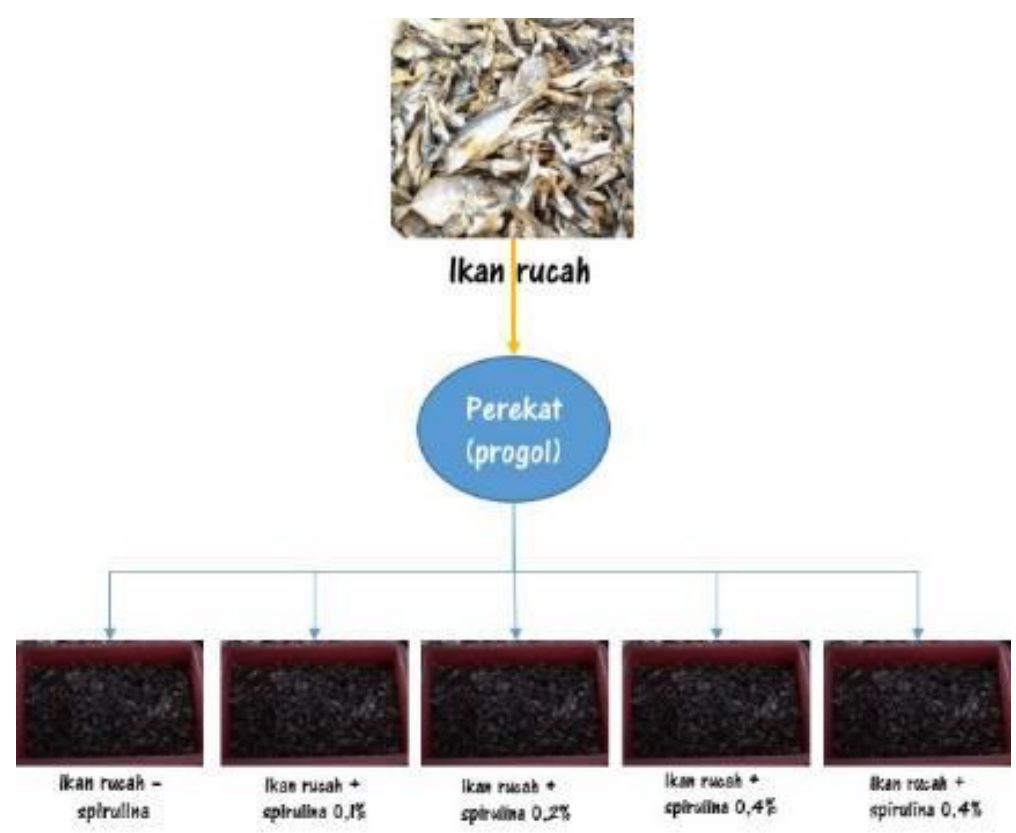

Gambar 3. Suplementasi pakan dengan spirulina

\section{Metode dan Prosedur Pelaksanaan}

Metode pelaksanaan PkM adalah metode demonstrasi plot (demplot), dengan prosedur pelaksanaan untuk mendukung realisasi kegiatan PkM dengan langkah-langkah yang telah disepakati bersama antara lain sosialisasi kegiatan PkM, demonstrasi plot (demplot) budidaya lobster dengan pakan sublementasi sprirylina dan pendampingan (Gambar 4). 


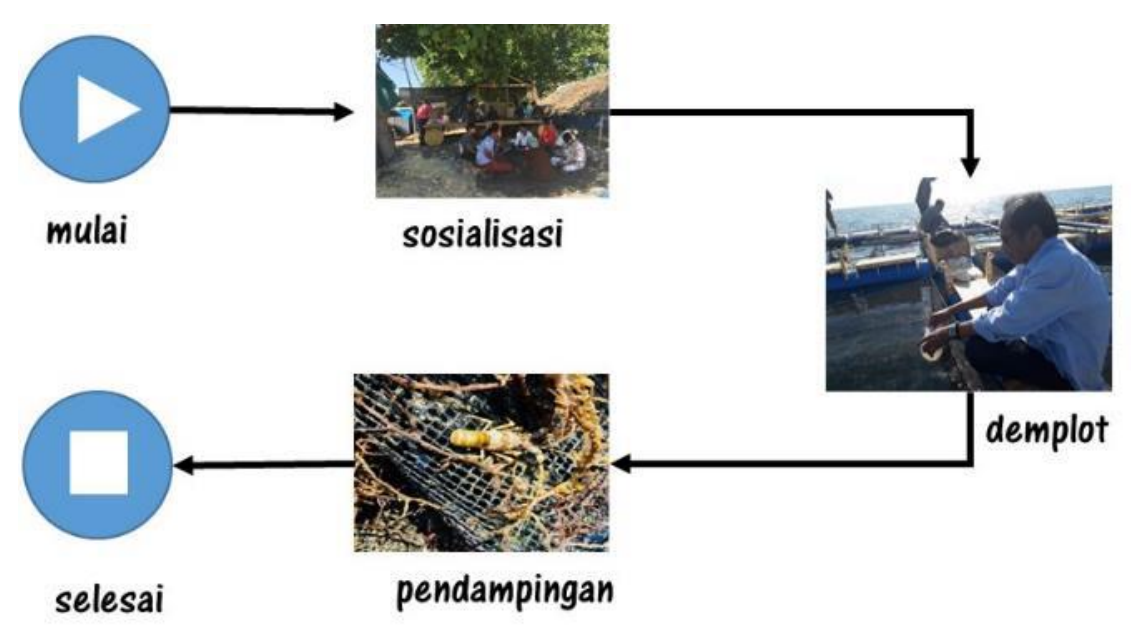

Gambar 4. Prosedur pelaksanaan pengabdian

1. Sosialisasi. Kegiatan sosialisasi dimaksudkan untuk meningkatkan kualitas pelaksanaan PkM ini, dan untuk menyamakan persepsi dengan para stakeholder, dengan harapan untuk mendapatkan respons yang baik sehingga kegiatan PkM ini dapat berjalan dengan baik dan lancar. Selain dihadiri pengurus dan anggota Pokdakan Mekar Bahari, kegiatan sosialisasi juga dihadari dinas dan instansi terkait, yaitu Pemerintah Daerah Kabupaten Lombok Utara, Kecamatan Tanung dan Desa Jenggala. Menurut Herdiana (2018) sosialisasi sebagai upaya memasyarakatkan suatu kebijakan yang telah dihasilkan perlu diketahui oleh masyarakat sehingga kebijakan tersebut selain dapat terlaksana dengan baik juga mendapatkan dukungan dari masyarakat.

2. Demonstrasi Plot (demplot). Demplot budidaya lobster dengan pakan suplemen dilakukan pada jaring apung sebanyak 15 unit, dengan cara mamasang pada 3 unit petak KJA. Kegiatan demplot diawali dengan pengadadaan bahan dan alat serta benih lobster, penebaran dan pemeliharaan selama dua bulan. Selama pemeliharaan diberikan pakan ikan rucah yang ditambahkan tepung spirulina sebanyak $0-0,4 \%$ dari ikan rucah. Pemberian pakan dilakukan 1 kali sehari pada sore hari.

3. Pendampingan. Pendampingan dilakukan dengan tujuan untuk membantu memecahkan masalah-masalah yang terjadi dalam menjalankan usaha budidaya lobster. Pendamping sebagai agen perubahan yang turut terlibat membantu memecahkan persoalan yag dihadapi kelompok masyarakat (Nugraha, 2009), dimana Tim PkM dan seorang Mahasiswa yang sedang penelitian skripsi di KJA milik Pokdakan Mekar Bahari, baik masalah teknis usaha maupun masalah manajemen kelompok. Selama pendampingan dilakukan pengukuran bobot dan jumlah individu setiap 20 hari untuk mengetahui tingkat pertumbuhan lobster dan kelangsungan hidupnya.

\section{Analisis Data}

Untuk mengetahui keberhasilan demplot budidaya lobster dengan pakan suplemen spirulina, maka dilakukan pengumpulan data pertumbuhan lobter yang dipelihara. Pengumpulan data dilakukan setiap 20 hari sekali dengan melakukan sampling lobster yang dipelihara pada setiap jaring. Parameter yang diamati adalah pertumbuhan pertumbuhan berat (weigh growth $=W G$ ), laju pertumbuhan spesifik (specific growth rate $=\mathrm{SGR}$ ) dan kelangsungan hidup (survival rate $=\mathrm{SR}$ ) mengacu pada (Junaidi \& Heriati, 2017; Ridwanudin et al., 2018) dengan persaman sebagai berikut : 
- Pertumbuhan berat (LG) :

- Laju pertumbuhan spesifik (SGR) :

$$
W G(\%)=100 \times \frac{\text { berat akhir }- \text { berat awal }}{\text { panjang awal }}
$$

$$
S G R(\% / \text { hari })=100 \times \frac{\text { Ln berat akhir }- \text { Ln berat awal }}{\text { lama pemeliharaan }}
$$

- Kelangsungan hidup (SR) :

$$
S R(\%)=100 \times \frac{\text { jumlah biota akhir }}{\text { jumlah biota awal }}
$$

\section{HASIL KEGIATAN}

Kegiatan sosialisasi kegiatan demplot budidaya lobster dengan pakan suplemen spirulina dilaksanakan pada hari Kamis tanggal 1 Agustus 2019 pukul 10.00 Wita bertempat di Rumah Jaga KJA milik Pokdakan Mekar Bahari. Kegiatan sosialisasi dihadiri 20 peserta yang terdiri dari Kepala Bidang Perikanan Budidaya dan Kepala Bidang Perikanan Tangkap Dinas Perhubungan dan Kelautan Kabupaten Lombok Utara, Penyuluh Perikanan, Babinsa, Bhayankantimas, Kepala Desa Jenggala, anggota dan pengurus Kelompok Mekar Bahari dan pendamping mahasiswa (Gambar 5). Keterlibatan berbagai pihak dalam sosialisasi tentunya akan dampak positif bagi keberhasilan program ini, dimana menurut Herdiana (2018) berbagai pihak yang terlibat akan memiliki sikap dan tindakan berupa kesadaran dan rasa tanggungjawab untuk menyukseskan implementasi kebijakan yang telah dibuat sesuai dengan perannya masing-masing.

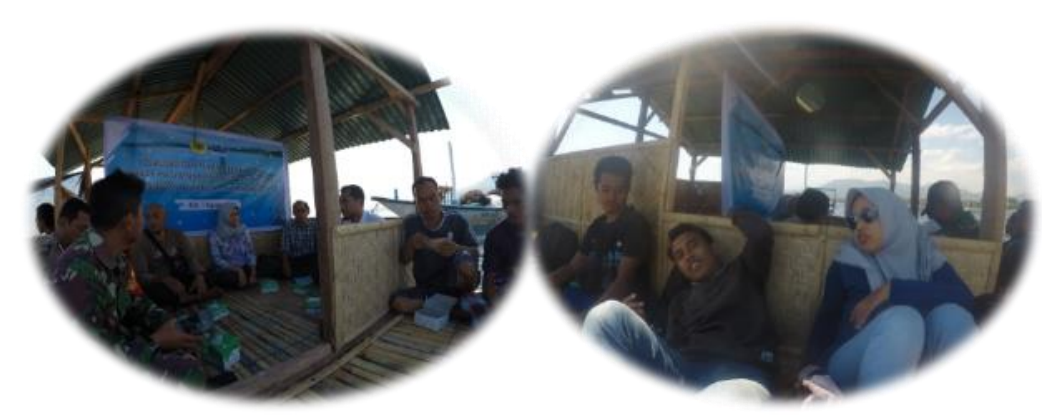

Gambar 5. Pelaksanaan sosialisasi kegiatan demplot budidaya lobster

Pada pelaksanaan demonstrasi plot (demplot), diawali dengan pembangunan rumah jaga dengan ukuran $5 \times 5 \mathrm{~m}$ yang terbuat dari kayu dan bambu dan agar rumah jaga terapung di atas permukaan air laut digunakan pelampung dari drumpun sebanyak 9 buah (Gambar 6). Rumah jaga ini ditempatkan disamping $\mathrm{KJA}$, selain berfungsi rumah jaga, bangunan ini juga berfungsi sebagai gudang dan balai pertemuan anggota Pokdakan Mekar Bahari. Sebagai wadah budidaya lobster digunakan jaring, dimana jaring digunakan untuk budidaya lobster dipasang rangkap yaitu jaring bagian dalam dan jaring luar. Penggunaan jaring rangkap ini dimaksudkan untuk mengurangi keboocoran akibat gigitan binatang lain. Ukuran jaring bagian luar mempunyai mata jaring (mesh size) yang lebih besar. Jaring bagian dalam berukuran mata 0,75 inci, disesuaikan dengan ukuran lobster, dimana benih lobster yang akan ditebar berukuran kecil. Sedangkan jaring bagian luar berukuran mata 1,5 inci, kedua jaring tersebut terbuat dari polyethylene (PE). Kantong jaring bagian dalam berukuran $1 \times 1 \times 1 \mathrm{~m}$, sedangkan bagian luar 3,5 x 3,5 ×3,5 m. . 


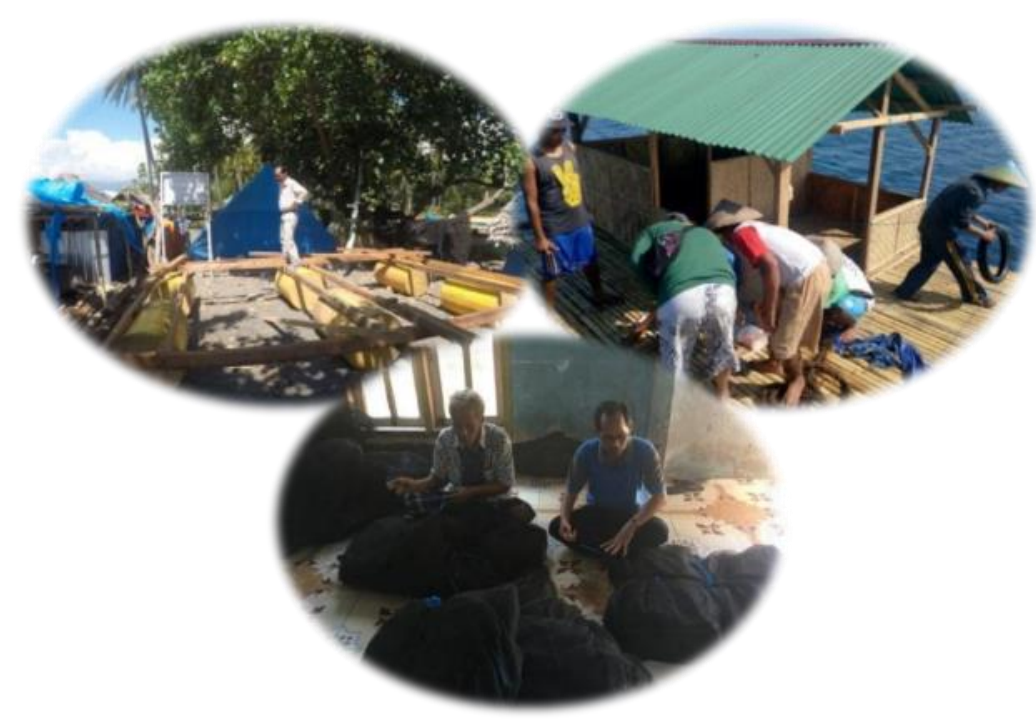

Gambar 6. Proses pembuatan rumah jaga dan perakitan jaring

Kegiatan penebaran lobster dilakukan pada tanggal 1 September 2019 sebanyak 300 ekor ditebar dalam 15 unit jaring yang berukuran $1 \times 1 \times 1 \mathrm{~m}$ atau dengan kepadatan $20 \mathrm{ekor} / \mathrm{m}^{2}$ dengan ukuran benih 3-6 $\mathrm{cm}$ (Gambar 7). Hal ini sesuai dengan hasil penelitian sebelumnya bahwa kepadatan lobster yang dipelihara dalam bak berkisar antara $20-30$ ekor $/ \mathrm{m}^{2}$ (Cokrowati et al., 2012). Selama pemeliharaan lobster yang berlangsung 2 bulan diberikan pakan setiap hari diberikan pakan sebanyak $5 \%$ dari bobot total. Pakan yang diberikan berupa ikan rucah yang diberikan suplemen tepung spirulina, dengan rincian 3 unit jaring diberikan pakan ikan rucah tanpa spirulina, 3 unit jaring diberikan ikan rucah + tepung spirulina 0,1\%, 3 unit jaring diberikan ikan rucah $+0,2 \%$ tepung spirulina, 3 unit jaring diberikan ikan rucah $+0,3 \%$ tepung spirulina, dan 3 unit jaring diberikan ikan rucah $+0,4 \%$ tepung spirulina,
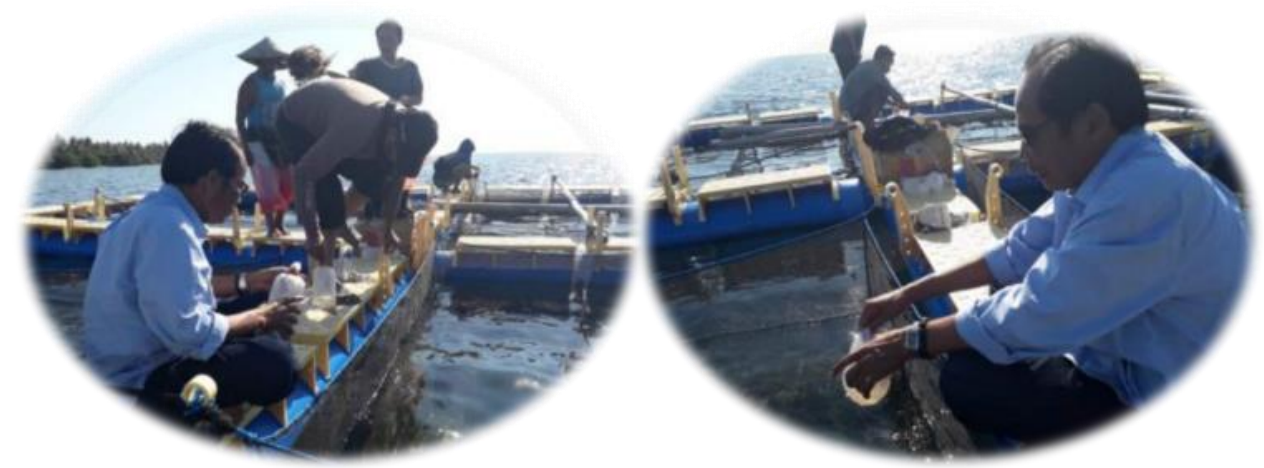

Gambar 7. Penebaran benih lobster

Kegiatan pendampingan oleh Tim Pengabdian dan seorang Mahasiswa yang sedang melakukan penelitian di KJA Pokdakan Mekar Bahari yang memiliki anggota 10 orang, dimana sebanyak 5 orang (50\%) yang termasuk kategori sangat aktif, 3 orang (30\%) aktif dan 2 orang (20\%) kurang aktif. Padahal melalui pendampingan diharapkan masyarakat pesisir bisa lebih mandiri dalam mengembangkan usaha budidaya kerang mutiara yang terintegrasi dengan budidaya lobster. Selain itu, dengan pendampingan dapat meningkatkan pengetahuan dan keterampilan dalam manajemen kewirausahaan. Selama pendampingan dilakukan pengukuran pertumbuhan berat lobster dan 
kelangsungan hidup setiap 20 hari dimulai pada bulan September sampai dengan Oktober 2019. Hasil analisis pertumbuhan berat (weigh growth $=W G$ ), laju pertumbuhan spesifik (specific growth rate = SGR) dan kelangsungan hidup (survival rate $=$ SR) dapat dilihat Gambar 8.

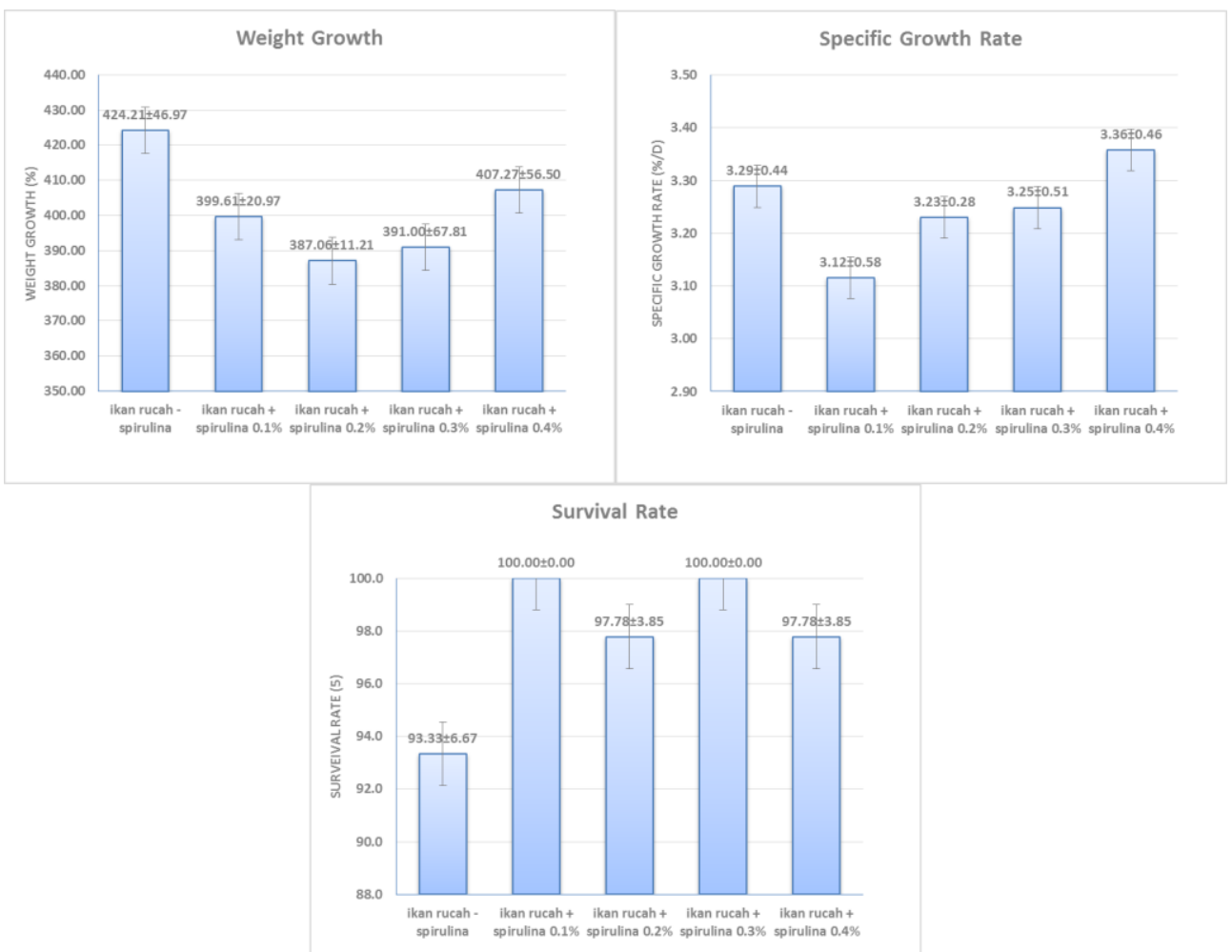

Gambar 8. Pertumbuhan berat, laju pertumbuhan spesifik dan kelangsungan hidup lobster

Hasil analisis pertumbuhan berat (weigth growth) lobster dengan budidaya sistem KJA dengan pakan suplementasi spirulina platensis selama 2 bulan berkisar antara 387,06 - 424,21 \%, laju pertumbuhan spesifik (specific growth rate) berkisar antara 3,12-3,36\%/hari dan kelangsungan hidup (survival rate) berkisar antara 93,33-100,00\%. Performa pertumbuhan dan kelangsungan hidup lobster pada kegiatan demplot ini tidak jauh berbeda dengan hasil penelitian sebelumnya (Junaidi \& Hamzah, 2014; Junaidi \& Heriati, 2017; Ridwanudin et al., 2018), dan penggunan pakan dengan suplemen spirlina memberi pengaruh yang signifikan pada laju pertumbuhan spesifik dan kelangsungan hidup lobster. Menurut Utomo et al. (2012) spirulina memiliki kandungan nutrisi yang cukup tinggi dengan potensi kandungan protein dan vitaminnya sehingga dapat dimanfaatkan sebagai sumber protein sel tunggal. Protein dari Spirulina platensis kering dapat mencapai lebih dari $60 \%$, kandungan vitaminnya tinggi terutama vitamin B12, serta mengandung asam amino yang cukup lengkap. Selain dapat meningkatkan kecerahan pada ikan hias, spirulina dapat meningkatkan performa pertumbuhan dan kelangsungan hidup (Hadijah et al., 2020).

Berdasarkan kegiatan demplot budidaya lobster sistem KJA dengan pakan suplementasi spirulina selama 2 bulan diperoleh performa pertumbuhan dan kelangsungan hidup lobster cukup bagus serta partisipasi masyarakat khususnya Pokdakan Mekar Bahari dan dukungan pemerintah daerah dalam kegiatan pengabdian ini. Diharapkan dengan selesainya kegiatan pelaksanaan pengabdian ini keberlanjutan program terus dilakukan bahkan diperluas, sehingga tujuan dan 
manfaat program dapat tercapai dan berkontribusi pada peningkatan kualitas hidup dan pendapatan masyarakat

\section{KESIMPULAN}

\section{Kesimpulan}

Demplot budidaya lobster dalam keramba jaring apung dengan pakan suplementasi spirulina dapat meningkatkan performa pertumbuhan dan kelangsungan hidup lobster cukup bagus serta tingkat partisipasi masyarakat yang relatif tinggi khususnya Kelompok Pembudidaya Ikan Mekar Bahari. Dengan demikian, kegiatan pengabdian ini memberi manfaat untuk peningkatan pengetahuan dan keterampilan kepada masyarakat.

\section{Saran}

Kegiatan pengabdian kepada masyarakat mampu meningkatkan performa pertumbuhan dan kelangsungan hidup lobster, maka diharapkan kegiatan ini terus dilanjutkan dan diperluas, sehingga tujuan dan manfaat program dapat tercapai dan berkontribusi pada peningkatan kualitas hidup dan pendapatan masayarakat

\section{UCAPAN TERIMA KASIH}

Ucapan terima kasih disampaikan kepada Kementerian Riset, Teknologi dan Pendidikan Tinggi (Kemenristekdikti) yang telah mendanai kegiatan Progran Kemitraan Masyarakat, Lembaga Penelitian dan Pengabdian kepada Masyarakat (LPPM) Universitas Mataram, Pemerintah Desa Jenggala, Bidang Perikanan Budidaya Dinas Perhubungan dan Kelautan Kabupaten Lombok Utara, dan Pokdakan Mekar Bahari yang telah mendukung dan mensukseskan program ini.

\section{DAFTAR PUSTAKA}

Bahrawi, S., Priyambodo, B., \& Jones, C. (2015). Census of the lobster seed fishery of Lombok. In Spiny lobster aquaculture development in Indonesia, Vietnam and Australia. Proceeding of the International Lobster Aquaculture Symposisum hleld in Lombok, Indonesia 22-25 April 2014 (pp. 12-19).

Cokrowati, N., Utami, P., \& Sarifin. (2012). Perbedaan padat tebar terhadap tingkat pertumbuhan dan kelangsungan hidup post peurulus lobster pasir (Panulirus homarus ). J. Kelautan, 5(2), 156-166.

Dian Herdiana. (2018). Sosialisasi Kebijakan Publik: Pengertian dan Konsep Dasar. Jurnal Ilmiah Wawasan Insan Akademik, 1(3), 13-26. Retrieved from https://scholar.google.co.id/scholar?cluster=6261633184899254674\&hl=en\&as_sdt=2005

Erlania, Radiarta, I. N., \& Haryadi, J. (2016). Status of spiny lobster seeds resouce management for aquaculture development: case study Lombok Island Waters. J. Kebijak. Perikan. Ind., 8(2), 8596. https://doi.org/http://dx.doi.org/10.15578/jkpi.8.2.2016.85-96

Hadijah, Junaidi, M., \& Lestari, D. P. (2020). Pemberian tepung Spirulina platensis pada pakan terhadap kecerahan warna ikan badut (Amphiprionocellaris). Jurnal Perikanan Unram, 10(1), 41-49. https://doi.org/10.29303/jp.v10i1.187

Jones, C. M. (2010). Tropical spiny lobster aquaculture development in Vietnam, Indonesia and Australia. J. Mar. Biol. Ass. India, 52(2), 304-315. Retrieved from http://mbai.org.in/php/journaldload.php?id=2175\&bkid=102\# 
Junaidi, M., \& Hamzah, M. sardi. (2014). Kualitas perairan dan dampaknya terhadap pertumbuhan dan sintasan udang karang yang dipelihara dalam keramba jaring apung di teluk ekas, provinsi nusa tenggara barat. J. Ilmu Dan Tek Kelautan Tropis, 6(2), 345-354.

Junaidi, M., \& Heriati, A. (2017). Pengembangan budidaya udang karang dalam keramba jaring apung di Teluk Ekas Provinsi Nusa Tenggara Barat. In Bunga Rampai Iptek Sumber Daya Pesisir untuk Pengemabngan Blue Economy di Pulau Lombok (pp. 111-123).

Junaidi, M., Lestary, D. P., \& Scabra, A. R. (2018). Mariculture Site Selection Based on Environmental Parameters in Tanjung and Gangga Sub-District, North Lombok. Proceedings The Ist Internatioal Confrences and Workshop on Bioscience and Prosperity, (November), 233-251.

Junaidi, M., Nurliah, \& Azhar, F. (2018). Conditions of Water Quality to Support Lobster Cultivation in North Lombok Regency, West Nusa Tenggara Province. J. Sains Teknologi \& Lingkungan, 4(2), 108-119.

Junaidi, M., Setyono, B. D. H., \& Azhar, F. (2020). Demplot Budi Daya Lobster dan Kerang Mutiara secara Terintegrasi dalam Rangka Penguatan Kemitraan Masyarakat Lombok Utara. Agrokreatif Jurnal Ilmi Pengabdian Kepada Masyarakat, 6(3), 249-259. https://doi.org/https://doi.org/10.29244/agrokreatif.6.3.249-259

Mustafa, A. (2013). Budidaya lobster (Panulirus sp .) di Vietnam dan aplikasinya di Indonesia. Media Akuakultur, 8(2), 73-84.

Nugraha, A. (2009). Pengembangan Masyarakat Pembangunan Melalui Pendampingan Sosial Dalam Konsep Pemberdayaan Di Bidang Ekonomi. Jurnal Ekonomi Modernisasi, 5, 10. Retrieved from http://ejournal.ukanjuruhan.ac.id

Ridwanudin, A., Fahmi, V., \& Pratama, S. (2018). Pertumbuhan Lobster Pasir Panulirus homarus dengan Pemberian Pakan Moist Abstrak Pendahuluan. Oseanologi Dan Limnologi, 3(21), 95-103. https://doi.org/10.14203/oldi.2018.v3i2.165

Utomo, N. B. P., Rahmatia, F., \& Setiawati, M. (2012). Penggunaan Spirulina platensis sebagai suplemen bahan baku pakan ikan nila Oreochromis niloticus The use of Spirulina platensis as tilapia Oreochromis niloticus diet supplementation. Jurnal Akuakultur Indonesia, 11(1), 49-53. 